Volume 10 Number 4, October-December 2016: pp. 605-820.

Copyright (c) 2015-2016 FIAT JUSTISIA. Faculty of Law, Lampung University, Bandarlampung, Lampung, Indonesia. ISSN: $1978-5186$ | e-ISSN: 2477-6238.

Open Access: http://jurnal.fh.unila.ac.id/index.php/fiat

Fiat Justisia is licensed under a Creative Commons Attribution 4.0 International License, which permits unrestricted use, distribution, and reproduction in any medium, provided the original work is properly cited.

\title{
PENGARUH PUTUSAN DEWAN KEHORMATAN PENYELENGGARA PEMILIHAN UMUM TERHADAP HASIL PEMILIHAN GUBERNUR LAMPUNG 2014
}

\section{The Effect of Decision of the Election Organizer Ethics Council to the Election Governor of Lampung 2014}

\author{
Aryo Fadlian \\ Law Office Paskalis Da Cunha \& Partner \\ Email: aryofadlian7@gmail.com
}

\begin{abstract}
The implementation process of the election of Governor of Lampung in 2014 was still a lot of controversy with the process so complicated that ultimately resulted elected leaders, after the long process, sprang DKPP decision relating to the election of the Governor of Lampung in 2014. The verdict of DKPP generates convicted and fired Lampung Provincial Election Supervisory Board The purpose of this research was to determine and analyze the strength of decision DKPP Lampung gubernatorial election in 2014. In this study the authors discussed the use of theory and concepts; theory of legislation, the concept of the State institutions, the concept of an independent State institution using normative juridical research method, i.e. obtaining secondary data obtained from the study of literature, books, and legislation. Results of research and discussion show that many violations in the elections in 2014 that resulted in the governor of Lampung in 2014 resulted in the termination of the Election Supervisory Board members Lampung province because it violates the code of ethics. Strength Honor Council Election decision final and binding give lessons to the election organizer Lampung Province.
\end{abstract}

Keywords: Verdict Strength, Election Organizer Ethics Council, Election Violations 


\begin{abstract}
Abstrak
Proses pelaksanaan pemilihan Gubernur Lampung tahun 2014 masih banyak kontroversi dengan prosesnya yang begitu rumit sehingga akhirnya menghasilkan pemimpin terpilih, setelah proses yang panjang, muncul keputusan DKPP terkait pemilihan Gubernur Lampung tahun 2014. Putusan tersebut DKPP menghasilkan terbukti dan dipecat Badan Pengawas Pemilu Provinsi Lampung. Tujuan dari penelitian ini adalah untuk mengetahui dan menganalisis kekuatan keputusan pemilihan gubernur DKPP Lampung pada tahun 2014. Dalam penelitian ini penulis membahas penggunaan teori dan konsep; Teori perundang-undangan, konsep lembaga negara, konsep lembaga negara merdeka yang menggunakan metode penelitian yuridis normatif, yaitu memperoleh data sekunder yang diperoleh dari studi literatur, buku dan perundang-undangan. Hasil penelitian dan pembahasan menunjukkan bahwa banyak pelanggaran dalam Pemilu 2014 yang mengakibatkan Gubernur Lampung pada tahun 2014 mengakibatkan penghentian anggota Badan Pengawas Pemilu Provinsi Lampung karena melanggar kode etik. Keputusan Kehormatan Dewan Kehormatan keputusan final dan mengikat memberi pelajaran kepada penyelenggara pemilu Provinsi Lampung.
\end{abstract}

Kata Kunci: Kekuatan Putusan, Dewan Kehormatan Penyelenggara Pemilihan Umum, Pelanggaran Pemilu

\title{
A. Pendahuluan
}

Berkembangnya demokrasi di Indonesia dengan mengacu pada negara-negara luar yang semakin berkembang pesat demokrasinya di era reformasi ini para elit politik pejabat-pejabat pemerintah dan didukung oleh rakyat memperbaiki sedikit demi sedikit sistem pemilihan pejabat publik yang kredibel, bersih dan berkompeten sesuai dengan keinginan rakyat Indonesia pada umumnya. Pembenahan ini tentunya tidak bisa dilakukan dengan mudah membutuhkan perjuangan yang sangat sulit dan dukungan penuh dari semua penjuru masyakat Indonesia dari berbagai lapisan. Sebagai bentuk realisasi kedaulatan rakyat dalam bingkai demokrasi adalah terselenggaranya Pemilihan Umum secara reguler dengan prinsip yang bebas, langsung, umum dan rahasia. Pemilu merupakan mandat dari konstitusi yang wajib dilaksanakan oleh pemerintah, dalam hal ini memastikan dan melindungi pelaksanaan kedaulatan rakyat dalam menyalurkan hak-hak politiknya dalam Pemilu. Pemilu sebagai salah satu praktek berlangsungnya kekuasaan dan pemerintah harus berdasarkan prinsip-prinsip hukum yang berkeadilan dan nilai-nilai kemanfaatan. Salah satu prinsip dasar dari negara hukum demokratis adalah adanya jaminan yang berkeadilan bagi rakyat dalam mengekspresikan kedaulatanya. 
Pelaksanaan Pemilu merupakan kehendak bangsa Indonesia untuk mengkokohkan dirinya sebagai negara demokratis. Pemilu pertama Tahun 1955 dilaksanakan dalam situasi bangsa Indonesia sedang mempertahankan kemerdekaanya. Dalam penilaian umum, Pemilu Tahun 1955 merupakan Pemilu yang ideal karena berlangsung demokratis. Sebaliknya Pemilu yang digelar sepanjang era Orde Baru hanya sekedar seremonial untuk mempertahankan kekuasaan, dengan merekayasa peraturan hukum, sistem, tata cara, dan hasil Pemilu-nya sekaligus. Arus reformasi berhasil mengoreksi praktek-praktek Pemilu yang tidak demokratis tersebut. Pemilu pertama di era reformasi digelar pada Tahun 1999, tidak saja bertujuan untuk membangun Indonesia yang demokratis, namun juga diharapkan mampu meletakan dasar kepemimpinan yang berpihak pada usaha-usaha pencapaian kemakmuran dan keadilan bagi rakyat.

Setiap penyelenggaraan Pemilu seringkali muncul persoalan atau pelanggaran Pemilu. Persoalan-persoalan tersebut muncul karena ketidak puasan terhadap penyelenggara Pemilu dalam hal ini Komisi Penyelenggara Pemilu (KPU), seperti keputusan/kebijakan yang tidak tepat merugikan peserta Pemilu, kekurang cermat dalam penghitungan suara, hingga indikasi keberpihakkan kepada salah satu peserta Pemilu, seperti pemalsuan identitas, intimidasi dan money politik kepada pemilih. Persoalan-persoalan tersebut apabila dibiarkan dan tidak diberikan mekanisme penyelesaianya (mekanisme hukum) yang jelas dan tegas, mengganggu kelancaran/kesuksesan Pemilu dan mengakibatkan rendahnya kredibilitas serta legitimasi Pemilu. Pada giliranya dapat mengancam dan mengabaikan hak-hak konstitusionalisme para peserta Pemilu dan masyarakat pada umumnya.

Setelah Pemilu pada Tahun 1999 Pemilu kedua era reformasi berlangsung Tahun 2004, pada saat itu masih banyak sekali pelanggaran. Meskipun banyak sekali pelanggaran peraturan maupun pelanggaran kode etik yang dilakukan KPU tidak begitu responsif menindak lanjuti dan hanya mengandalkan hasil keputusan pengadilan. Pemilu ketiga di era reformasi yaitu pada Tahun 2009 dimaksudkan untuk semakin menyempurnakan dari pemilu-pemilu sebelumnya,tapi pada Pemilu Tahun 2009 tetap mengalami berbagai pelanggaran.

Setelah Tahun 2009 Pemilu kembali dilaksanakan pada Tahun 2014 khususnya provinsi lampung serempak pelaksanaan Pemilu legislatif dengan dilaksanakan Pemilihan Gubernur Lampung periode 2014-2019.

Pada awalnya Pilgub Lampung pernah mengalami kontroversi yaitu pada saat Tahun 2002 Alzier Dianis Thabrani terpilih menjadi Gubernur Lampung namun karena tersangkut tindak pidana tidak jadi dilantik oleh Mendagri. Setelah itu hasil rapat paripurna DPRD Prov Lampung Tahun 2004 memenangkan pasangan Sjachroedin ZP-Syamsurya Ryacudu dengan 
mengalahkan pasangan Oemarsono-Ibrahim BS, untuk menjabat Gubernur Lampung periode tahun 2004-2009. ${ }^{1}$

Pemilihan Gubernur selanjutnya dilaksanakan langsung dipilih oleh rakyat pada Tahun 2008. Sjachroedin ZP mengundurkan diri sebagai Gubernur dan digantikan oleh Syamsurya Ryacudu yang sebelumnya sebagai Wakil Gubernur Lampung menjadi Gubernur definitif karena Sjachroedin ZP ingin mencalonkan diri kembali pada pertarungan Pemilihan Gubernur Lampung Tahun 2008. Dengan berpasangan dengan MS Joko Umar Said, Sjachroedin ZP memenangkan kembali sebagai Gubernur Lampung periode 2009-2014. ${ }^{2}$

Perdebatan dan adu argumentasi pada Pemilihan Gubernur Lampung 2014 sangat rumit, sangat berlarutnya polemik Pilgub menjadi presiden buruk yang memalukan daerah, karena sudah berulang kali Lampung mencatatkan sejarah buruk di momentum pesta demokrasi lima tahunan ini. Bermula dari terbitnya SK KPUD Lampung No.75/Kpts/KPU-Prov008/2012 tertanggal 11 September 2012 tentang hari pemungutan suara Pemilihan Gubernur dan Wakil Gubernur Tahun 2013, yang menegaskan putaran pertama akan dilakukan pada 2 Oktober Putaran kedua disiapkan pada 4 Desember. Gubernur menolak dengan tidak memasukan anggaran Pilkada dalam APBD-P 2013. Dengan begitu, Pilgub diundur hingga Tahun 2015 dengan pertimbangan belum adanya dasar hukum yang kuat. Karena RUU Pemilukada belum disahkan oleh DPR RI. Kementrian Dalam Negri dan DPRD Provinsi pun memilih jalan tengah dan hanya mendapatkan kata sepakat. Gubernur menawarkan akan disediakan pada APBD 2014 dengan dilaksanakan bulan januari Mendagri menawarkan bulan april 2014 pelaksanaan bersamaan dengan Pileg. Bahkan sempat muncul wacana solusi agar ara calon yang sedang menjabat Kepala Daerah untuk sementara urunan Rp 50.000.000.000 dari dana sisa bagi hasil APBD masing-masing. Dengan diperpanjangkannya masa jabatan 5 orang komisioner KPU Lampung hingga pelantikan Gubernur terpilih 2014-2019 melalui SK KPU-RI No.707/Kpts/KPU/Tahun 2013 tertanggal 12 September, dan dengan landasan hukum UU No.32 Tahun 2004, PP No. 6 Tahun 2005 dan Peraturan KPU No. 9 Tahun 2010, maka tahapan yang tertunda patutlah segera dimulai kembali. Semua pihak harus lebih tegas dan proaktif menuntaskan semua persoalan. ${ }^{3}$

Dalam Pemilihan Gubernur Lampung 2014 yang akhirnya pelaksanaannya membarengi pemilihan legislatif pada tanggal 9 April 2014

\footnotetext{
${ }^{1}$ http://www.tokohindonesia.com/biografi/article/286-direktori/2339-terpilih-jadi-gubernurlampung (diakses dan diunduh tanggal 25-2-2015)

${ }^{2}$ http://www.republika.co.id/berita/breaking-news/nasional/08/09/18/3734-kpud-lampungtetap-gelar-rekapitulasi-suara-pilgub (diakses dan diunduh tanggal 25-2-2015)

${ }^{3}$ Irawan, Nyoman Adi. 2013. Mahasiswa Untuk Demokrasi, p. 1.
} 
diikuti oleh 4 pasang calon Gubernur dan calon Wakil Gubernur yaitu Nomor urut 1. Berlian Tihang-Mukhlis Basri, Nomor urut 2. Ridho FicardoBachtiar, Nomor urut 3. Herman HN-Zainudin Hasan, Nomor urut 4. Alzier Dianis Thabrani-Lukman Hakim. Dengan Daftar pemilih tetap kurang lebih 5,8 juta jiwa dilaksanakan di 16.497 TPS.

Berdasarkan hasil quick count SMRC (Saiful Muzani Research Center) pasangan Ridho Ficardo-Bachtiar memperoleh 43,66 \% suara dan diikuti oleh Herman HN-Zainudin Hasan memperoleh 32,94 \% suara sedangkan Berlian Tihang-Muchlis Basri 15,7 \% dan Alzier Dianis Thabrani-Lukman Hakim memperoleh 7,7 \% suara. Berbanding terbalik dengan SMRC, real count versi Pussbik Lampung pasangan Herman HNZainudin Hasan mengungguli pasangan Ridho-Bachtiar. ${ }^{4}$

Hasil rapat pleno KPU Provinsi Lampung tanggal 17 april 2014 yang dibacakan langsung oleh Ketua KPU Provinsi Lampung Nanang Trenggono memenangkan pasangan Ridho-Bachtiar pada Pemilihan Gubernur dan Wakil Gubernur Lampung 2014-2019 dengan memperoleh 1.816.533 suara $(44,96 \%){ }^{5}$

Lahirnya Undang-Undang Nomor 15 Tahun 2011 tentang Penyelenggara Pemilu (selanjutnya disingkat UU No. 15 Tahun 2011), mengamanatkan untuk membentuk suatu lembaga negara baru, yaitu Dewan Kehormatan Penyelenggara Pemilu (selanjutnya disingkat DKPP). DKPP adalah lembaga yang bertugas menangani pelanggaran kode etik Penyelenggara Pemilu dan merupakan satu kesatuan fungsi Penyelenggara Pemilu. DKPP memiliki tugas dan wewenang untuk menegakan dan menjaga kemandirian, integritas, dan kredibelitas Penyelenggara Pemilu. Secara lebih spesifik DKPP dibentuk untuk memeriksa, mengadili dan memutuskan pengaduan/laporan dugaan pelanggaran kode etik yang dilakukan anggota KPU, anggota Bawaslu, dan jajaran di bawahnya.

Pada hari Selasa 12 Juni 2012 Presiden melantik tujuh anggota DKPP periode Tahun 2012-2017 di Istana Negara. Pengurus DKPP dituangkan dalam Keppres Nomor 57 Tahun 2012. Ketujuh anggota DKPP tersebut adalah Ida Budhiarti mewakili unsur KPU, Nelson Simanjuntak mewakili unsur Bawaslu dan lima dari unsur masyarakat yaitu AbdulBari Azed, Valina Singka Subekti, Jimly Asshiddiqie, Saut Hamonangan Sirait serta Nur Hidayat Sardini.

Sejak berdirinya DKPP, sangat produktif menangani perkara pengaduan pelanggaran kode etik oleh Penyelenggara Pemilu. Sampai bulan

\footnotetext{
${ }^{4} \mathrm{http} / /$ sidomi.com/280499/hasil-pilgub-lampung-2014-ridho-bakhtiar-menang-versi-quickcount/ (diakses dan diunduh tanggal 25-2-2015).

${ }^{5} \mathrm{http}: / /$ www.saibumi.com/artikel-2622-hasil-final-rekapitulasi-kpu-ridho-ficardo-menangipilgub-lampung-dengan-4496-persen.html (diakses dan diunduh tanggal 25-2-2015).
} 
November Tahun 2012, DKPP telah memproses perkara pelanggarana kode etik Penyelenggara Pemilu sejumlah 53 perkara. Namun mengingat dalam penanganan perkara lazim didasarkan pada pihak yang diadukan (teradu).

Begitu besarnya pengaruh DKPP dalam suatu proses Penyelenggara Pemilu dan fenomena kemunculan lembaga negara baru yang membawa perubahan dalam struktur ketatanegaraan dan tatanan pemerintah, menjadi suatu hal yang sangat penting dan menarik untuk dibahas lebih lanjut. Kehadiran lembaga DKPP yang berwibawa sebagai pilar demokrasi sangat diperlukan. DKPP tidak hanya diharapkan mampu meneggakan kode etik penyelenggara Pemilu, tetapi juga dapat mengawal independensi dan imparsialitas jajaran KPU dan Bawaslu dari pusat hingga daerah. Selain itu, keberadaan DKPP diharapkan dapat memberikan kepastian dan jaminan bagi Pemilu yang jujur, adil, bebas, rahasia.

Pendekatan yang dilakukan dalam penelitian ini menggunakan metode pendekatan yuridis normatif, yaitu pendekatan yang dilakukan dengan mempelajari dan menganalisis teori-teori, konsep-konsep, literatur dan peraturan perundang-undangan yang berhubungan dengan permasalahan penelitian.

\section{B. Pembahasan}

\section{Proses Pelaksanaan Pemilihan Gubernur Lampung tahun 2014 jika Ditinjau dari Putusan DKPP}

Demokrasi sebagai aspek penting berkaitan dengan pemerintahan dengan hierarkhi kekuasaan yang terdapat dalam suatu sistem politik negara. Artinya, akan terdapat sistem politik nasional yang didalamnya terdapat sub sistem politik daerah dalam bingkai sistem negara yang dianutnya. Pemilahan demokrasi lokal ini bukan berarti terdapat determinasi wilayah pemberlakuan demokrasi atau bahkan terdapat perbedaan demokrasi dari induknya. Dalam tulisan ini demokrasi lokal.

Ditujukan sebagai bagian utuh dari demokrasi di Indonesia. Pemilukada langsung merupakan wujud nyata asas responsibilitas dan akuntabilitas karena Pemilukada langsung akan memperkuat legitimasi seorang kepala daerah karena ia dipilih lansung oleh rakyat.

Dengan Pemilukada langsung maka akan memperkuat legitimasi seorang kepala daerah karena ia dipilih langsung oleh rakyatnya. Elit politik atau partai politik tidak bisa lagi menjatuhkan seenaknya seorang kepala daerah (kecuali ia melakukan tindakan kriminal dan menghianati negara atau makar) karena ia merupakan pilihan rakyat, suara rakyat adalah pilihan rakyat dan suara rakyat adalah suara Tuhan (vox populi vox dey). Oleh karena itu seorang presiden yang dipilih secara secara langsung memiliki legitimasi yang tinggi. 
Pemilu eksekutif daerah ini berada dalam koridor demokrasi lokal dalam lingkup asas pemerintahan yang desentralisasi dan didasarkan pada rel kebijakan publik UU No. 32 tahun 2004 tentang Pemerintahan Daerah.

Dalam Pemilihan Gubernur Lampung 2014 yang akhirnya pelaksanaanya membarengi pemilihan legislatif pada tanggal 9 April 2014 diikuti oleh 4 pasang calon Gubernur dan calon Wakil Gubernur yaitu Nomor urut 1. Berlian Tihang-Mukhlis Basri, Nomor urut 2. Ridho FicardoBachtiar, Nomor urut 3. Herman HN-Zainudin Hasan, Nomor urut 4. Alzier Dianis Thabrani-Lukman Hakim. Dengan Daftar pemilih tetap kurang lebih 5,8 juta jiwa dilaksanakan di 16.497 TPS.

Berdasarkan hasil quick count SMRC (Saiful Muzani Research Center) pasangan Ridho Ficardo-Bachtiar memperoleh 43,66 \% suara dan diikuti oleh Herman HN-Zainudin Hasan memperoleh 32,94 \% suara sedangkan Berlian Tihang-Muchlis Basri 15,7 \% dan Alzier Dianis Thabrani-Lukman Hakim memperoleh $7,7 \%$ suara. Berbanding terbalik dengan SMRC, real count versi Pussbik Lampung pasangan Herman HNZainudin Hasan mengungguli pasangan Ridho-Bachtiar. ${ }^{6}$

Hasil rapat pleno KPU Provinsi Lampung tanggal 17 april 2014 yang dibacakan langsung oleh Ketua KPU Provinsi Lampung Nanang Trenggono memenangkan pasangan Ridho-Bachtiar pada Pemilihan Gubernur dan Wakil Gubernur Lampung 2014-2019 dengan memperoleh 1.816 .533 suara $(44,96 \%)^{7}$

Lahirnya Undang-Undang Nomor 15 Tahun 2011 tentang Penyelenggara Pemilu (selanjutnya disingkat UU No. 15 Tahun 2011), mengamanatkan untuk membentuk suatu lembaga negara baru, yaitu Dewan Kehormatan Penyelenggara Pemilu (selanjutnya disingkat DKPP). DKPP adalah lembaga yang bertugas menangani pelanggaran kode etik Penyelenggara Pemilu dan merupakan satu kesatuan fungsi Penyelenggara Pemilu. DKPP memiliki tugas dan wewenang untuk menegakkan dan menjaga kemandirian, integritas, dan kredibelitas Penyelenggara Pemilu. Secara lebih spesifik DKPP dibentuk untuk memeriksa, mengadili dan memutuskan pengaduan/laporan dugaan pelanggaran kode etik yang dilakukan anggota KPU, anggota Bawaslu, dan jajaran di bawahnya.

Pada hari Selasa 12 Juni 2012 Presiden melantik tujuh anggota DKPP periode Tahun 2012-2017 di Istana Negara. Pengurus DKPP dituangkan dalam Keppres Nomor 57 Tahun 2012. Ketujuh anggota DKPP tersebut adalah Ida Budhiarti mewakili unsur KPU, Nelson Simanjuntak mewakili

\footnotetext{
${ }^{6} \mathrm{http}: / /$ sidomi.com/280499/hasil-pilgub-lampung-2014-ridho-bakhtiar-menang-versi-quickcount/ (diakses dan diunduh tanggal 25-2-2015).

${ }^{7}$ http://www.saibumi.com/artikel-2622-hasil-final-rekapitulasi-kpu-ridho-ficardo-menangipilgub-lampung-dengan-4496-persen.html (diakses dan diunduh tanggal 25-2-2015).
} 
unsur Bawaslu dan lima dari unsur masyarakat yaitu AbdulBari Azed, Valina Singka Subekti, Jimly Asshiddiqie, Saut Hamonangan Sirait serta Nur Hidayat Sardini.

Sejak berdirinya DKPP, sangat produktif menangani perkara pengaduan pelanggaran kode etik oleh Penyelenggara Pemilu. Sampai bulan November Tahun 2012, DKPP telah memproses perkara pelanggarana kode etik Penyelenggara Pemilu sejumlah 53 perkara. Namun mengingat dalam penanganan perkara lazim didasarkan pada pihak yang diadukan (teradu).

Begitu besarnya pengaruh DKPP dalam suatu proses Penyelenggara Pemilu dan fenomena kemunculan lembaga negara baru yang membawa perubahan dalam struktur ketatanegaraan dan tatanan pemerintah, menjadi suatu hal yang sangat penting dan menarik untuk dibahas lebih lanjut. Kehadiran lembaga DKPP yang berwibawa sebagai pilar demokrasi sangat diperlukan. DKPP tidak hanya diharapkan mampu meneggakan kode etik penyelenggara Pemilu, tetapi juga dapat mengawal independensi dan imparsialitas jajaran KPU dan Bawaslu dari pusat hingga daerah. Selain itu, keberadaan DKPP diharapkan dapat memberikan kepastian dan jaminan bagi Pemilu yang jujur, adil, bebas, rahasia.

Kemenangan Ridho-Bachtiar ternodai oleh banyaknya pelanggaranpelanggaran pemilu seperti money politik, etika kampanye dan terindikasi mengubah hasil suara di beberapa TPS. Dan keputusan Dewan Kehormatan Penyelenggara Pemilu No.25/DKPP-PKE-III/2014 menyimpulkan bahwa Bawaslu Provinsi Lampung melakukan pelanggaran kode etik Penyelenggara Pemilu, dan memerintahkan kepada Bawaslu pusat untuk menindaklanjuti sesuai dengan peraturan perundang-undangan. ${ }^{8}$

\section{Kekuatan dan Pelaksanaan Putusan DKPP Terhadap Pelanggaran Kode Etik Penyelenggara Pemilu \\ a. Subjek dan Objek Perkara Yang Ditanggani DKPP}

Untuk mengetahui seperti apa putusan DKPP, terlebih dahulu harus ditentukan siapa saja yang dapat menjadi subjek perkara dan objek yang dapat diperkarakan di DKPP. Berdasarkan Undang-Undang Nomor 15 Tahun 2011 Tentang Penyelenggara Pemilu, subjek yang dapat menjadi pihak yang berperkara di DKPP adalah anggota KPU, anggota KPU Provinsi, anggota KPU Kabupaten/Kota, anggota PPK, anggota PPS, anggota PPLN, anggota KPPS, anggota KPPSLN, anggota Bawaslu, anggota Bawaslu Provinsi dan anggota Panwaslu Kabupaten/Kota, anggota Panwaslu Kecamatan, anggota Pengawas Pemilu Lapangan dan anggota Pengawas Pemilu Luar Negeri.

\footnotetext{
${ }^{8}$ www.langpung.tribunnews.com/2014/6/09/dkpp-putusan-bawaslu-lampung-langgar-kodeetik (diakses dan diunduh tanggal 3-3-2015).
} 
Peraturan DKPP Nomor 2 Tahun 2012 Tentang Pedoman Berac Ara Kode Etik Penyelenggara Pemilihan Umum, Pasal 9 menyebutkan bahwa "Jika Teradu dan/atau Terlapor adalah Penyelenggara Pemilu yang menjabat sebagai (a) anggota KPU Kabupaten/Kota atau KIP Kabupaten/Kota; (b) anggota Panwaslu Kabupaten/Kota; (c) anggota PPK; (d) anggota Panwaslu Kecamatan; (e) anggota PPS; (f) anggota Pengawas Pemilu Lapangan; atau (f) anggota KPPS, Pengaduan dan/atau Laporan diajukan kepada DKPP melalui Bawaslu Provinsi". Bawaslu Provinsi melakukan penelitian kelengkapan administrasi Pengaduan dan/atau Laporan tersebut.

Subjek yang dapat menjadi pihak yang berperkara selaku pihak teradu dan/atau terlapor di DKPP sangatlah luas dan banyak. Walaupun Peraturan DKPP menentukan penyelenggara Pemilu tingkat Kabupaten/Kota kebawah pengaduan dan penelitian berkasnya melalui Bawaslu. Bahkan sebenarnya hal-hal yang dapat diselesaikan sendiri atau yang semestinya ditangani melalui mekanisme internal harus lah lebih dulu ditangani oleh KPU dan Bawaslu, tidak boleh secara langsung ditangani oleh DKPP.

Seluruh pengaduan pelanggaran kode etik langsung disampaikan dan ditangani oleh DKPP. Tidak mungkin DKPP dapat menangani pelanggaran kode etik yang dilakukan oleh penyelenggara Pemilu ditingkat Kecamatan sampai dengan lapangan yang jumlahnya ribuan orang dengan sifat kerja yang sementara dan bukan yang utama. Seharusnya kasus-kasus dugaan pelanggaran kode etik yang ditangani oleh DKPP hanya yang dilakukan oleh Penyelenggara pemilu di tingkat Kabupaten/Kota, Provinsi dan Pusat.

Peraturan bersama KPU, Bawaslu, dan DKPP tentang Kode Etik Penyelenggara Pemilihan Umum, Pasal 1 angka 6 menyebutkan bahwa "Kode Etik Penyelenggara Pemilu, selanjutnya disebut Kode Etik, adalah satu kesatuan landasan norma moral, etis dan filosofis yang menjadi pedoman bagi perilaku penyelenggara pemilihan umum yang diwajibkan, dilarang, patut atau tidak patut dilakukan dalam semua tindakan dan ucapan". Peraturan ini dapat ditentukan objek perkara yang ditangani oleh DKPP terbatas hanya kepada persoalan perilaku pribadi atau orang perorang pejabat atau petugas penyelenggara pemilihan umum.

Etika berasal dari bahasa yunani "ethos", yang berarti kebiasaan, adat, watak, perasaan, sikap dan cara berfikir. Istilah etika juga disebut juga "mores, mos" yang juga berarti adat istiadat atau kebiasaan yang baik, sehingga dari istilah ini lahir penyebutan moralitas atau moral. Etika melekat pada manusia pribadi dengan tuntutan atas dasar kehendak bebas dalam kaitannya membentuk manusia yang berpribadi manusia, dengan demikian akan memiliki tanggung jawab dan kewajiban serta sanksi sosial.

Perilaku etis penyelenggara Pemilu dapat dinilai dengan kemamampuannya menyelenggarakan pemilu dengan berpegang pada 12 asas penyelenggaraan Pemilu yakni: mandiri, jujur, adil, kepastian hukum, 
tertib, kepentingan umum, keterbukaan, proporsionalitas, profesionalitas, akuntabilitas, efisiensi, dan efektivitas. Pihak yang melaporkan atau yang mengadu harus mampu membuktikan apa saja yang telah dilakukan oleh orang per orang individu ketua atau anggota KPU atau Bawaslu yang dianggap telah melanggar kode etik penyelenggara pemilu sesuai ketentuan yang berlaku. Modus pelanggaran kode etik penyelenggara Pemilu yang sudah dan tengah disidangkan DKPP didominasi pembatalan kepesertaan dalam Pemilukada, menyangkut persyaratan pencalonan, keterpenuhan cakupan dan jumlah persyaratan, dan lewatnya waktu pencalonan, serta tafsir terhadap ketentuan persyaratan pencalonan.

Objek pelanggaran etika yang dapat diperkarakan menyangkut sikap dan perbuatan yang mengandung unsur jahat dan melanggar hukum yang dilakukan oleh perseorangan individu secara sendiri-sendiri atau pun bersama-sama yang dipertanggung-jawabkan juga secara individu orang perorang. Jadi jelas yang dapat diperkarakan dan dituduh melanggar kode etik bukan KPU atau Bawaslu sebagai institusi, tetapi orang per orang yang menduduki jabatan sebagai ketua atau anggota KPU atau Bawaslu tersebut.

Dalam Undang-Undang Penyelenggara Pemilu dan Peraturan DKPP mengenai pengajuan perkara pelanggaran kode etik oleh penyelenggara Pemilu tidak memiliki batasan waktu tertentu. Walaupun pelanggaran itu sudah lama terjadi dan hasil pemilunya telah disahkan secara hukum, tetap bisa diajukan ke DKPP apabila ditemukan adanya dugaan pelanggaran kode etik yang dilakukan oleh penyelenggara Pemilu.

DKPP sebagai lembaga etik memang benar tidak ada batasan waktu mengenai pengaduan suatu pelanggaran kode etik. Jadi objek perkara di DKPP tidak tergantung kepada "tempos delicti" atau saat kapan suatu perbuatan melanggar kode etik. Hal ini dikarenakan antara persoalan pelanggaran kode etik aparat KPU dan Bawaslu dengan proses Pemilu dan bahkan dengan persoalan sengketa mengenai hasil pemilihan itu, tidak dapat dikaitkan berdasarkan prinsip sebab-akibat atau kausalitas.

Seperti pada Putusan DKPP No.9/DKPP-PKE-I/2012 ${ }^{10}$ yang memberhentikan Ketua KPU Depok secara tetap karena terbukti melanggar kode etik, padahal Pemilukada Kota Depok telah berlangsung dua tahun sebelumnya dan putusan sengketa hasil pemilu telah bersifat final dan mengikat berdasarkan putusan

Mahkamah Konstitusi yang telah dilaksanakan oleh Komisi Pemilihan Umum Putusan DKPP tersebut tidak dapat dijadikan dasar untuk memberhentikan Walikota yang telah terpilih. Saat ini terbuka ruang yang

\footnotetext{
${ }^{9}$ Jimly Asshiddiqie, Pengenalan DKPP Untuk Penegakan Hukum, Makalah disampaikan dalam forum Rapat Pimpinan Kepolisian Republik Indonesia di Jakarta, Februari 2013.

${ }^{10} \mathrm{http} / / / \mathrm{dkpp} . c e n t r a l . n e t . i d /$ index.php?mod=maklist\&id=55000000007, (diakses dan diunduh tanggal 2-2-2015)
} 
sangat luas untuk menggugat penyelenggara Pemilu yang bekerja secara tidak profesional. Tidak adanya batasan waktu mengajukan gugatan pelanggaran kode etik dapat membuat terjadinya suasana yang tidak menentu dimasyarakat dan rasa khawatir para penyelenggara Pemilu apabila suatu saat mereka digugat ke DKPP. Menurut penulis sebaiknya khusus dalam penyelenggaraan suatu Pemilu, pengajuan gugatan pelanggaran kode etik dibatasi sesuai tahapan Pemilu yang dilalui atau paling tidak sampai satu bulan selesainya penyelenggaraan suatu Pemilu. Adanya pembatasan ini juga bermanfaaat pada putusan DKPP yang dapat menjadi dasar atau pertimbangan terhadap gugatan pelanggaran tindak pidana Pemilu, sengketa tata usaha negara Pemilu dan perselisihan hasil Pemilu.

\section{b. Sifat Putusan DKPP Final dan Mengikat}

Suatu hal yang sangat menarik dari penegakan kode etik yang dilakukan oleh $\mathrm{DKPP}^{11}$ adalah sifat putusan yang final dan mengikat serta wajib dilaksanakan (executable). Selain itu mengenai mekanisme penanganan pengaduan pelanggaran kode etik yang dilakukan melalui persidangan yang terbuka dan disertai dengan pengujian alat bukti (semi peradilan). Dari dua hal tersebut menyebabkan DKPP saat ini di usia yang baru satu tahun sudah sangat dikenal

luas dan keberadaaanya sangat dihormati dan disegani oleh semua pihak yang terkait dalam proses penyelenggaraan Pemilu. Dalam putusannya, DKPP tidak segan-segan untuk memecat penyelenggara Pemilu yang terbukti telah melakukan pelanggaran kode etik yang berat.

Putusan DKPP berupa sanksi atau rehabilitasi sanksi tersebut dapat berupa teguran tertulis, pemberhentian sementara, atau pemberhentian tetap, sebagai mana diatur dalam Pasal 112 ayat (10 dan 11) Undang-Undang Nomor 15 Tahun 2011 Tentang Penyelenggara Pemilu. Dalam hal amar putusan DKPP menyatakan Pengaduan dan/atau Laporan tidak dapat diterima atau Teradu dan/atau Terlapor tidak terbukti melanggar, maka DKPP melakukan rehabilitasi kepada Teradu dan/atau Terlapor. Undangundang Penyelenggara Pemilu dan Peraturan DKPP menyatakan dengan tegas bahwa Putusan DKPP bersifat final dan mengikat (final and binding) serta penyelenggara Pemilu wajib melaksanakan putusan DKPP tersebut.

Pasal 28 ayat (3) UU No.15 Tahun 2011 menyebutkan bahwa "Dalam hal rapat pleno DKPP memutuskan pemberhentian anggota sebagaimana dimaksud pada ayat (1), anggota yang bersangkutan diberhentikan sementara sebagai anggota KPU, KPU Provinsi, atau KPU Kabupaten/Kota sampai

\footnotetext{
${ }^{11}$ Dalam setiap pemberitaan media cetak dan elektronik tentang DKPP selalu disebutkan menggenai putusan DKPP bersifat yang final dan mengikat.
} 
dengan diterbitkannya keputusan pemberhentian". Kemudian Pasal 100 ayat (4) juga menyebutkan bahwa "Dalam hal rapat pleno DKPP memutuskan pemberhentian anggota sebagaimana dimaksud pada ayat (1) dan ayat (2), anggota yang bersangkutan diberhentikan sementara sebagai anggota Bawaslu, Bawaslu Provinsi, Panwaslu Kabupaten/Kota, Panwaslu Kecamatan, Pengawas Pemilu Lapangan, dan Pengawas Pemilu Luar Negeri sampai dengan diterbitkannya keputusan pemberhentian".

Apabila dalam suatu perkara pelanggaran kode etik, DKPP memutuskan memberhentikan anggota KPU Kabupaten/Kota, maka KPU Provinsi menindaklanjutinya dengan menerbitkan Surat Keputusan Pemberhentian yang bersangkutan dari kedudukannya sebagai anggota KPU Kabupaten/Kota. Hal yang sama juga berlaku bagi Bawaslu disemua tingkatan. Khusus KPU Pusat dan Bawaslu Pusat apabila terbukti melanggar kode etik dan diberhentikan oleh putusan DKPP, maka surat pemberhentiannya harus dituangkan dalam bentuk Keputusan Presiden. Surat Pemberhentian hanya bersifat administrasi, karena pemberhentiannya berlaku sejak tanggal putusan DKPP dibacakan atau diucapkan dalam sidang pleno yang terbuka untuk umum.

Putusan DKPP bersifat final artinya tidak tersedia lagi upaya hukum lain atau upaya hukum yang lebih lanjut sesudah berlakunya putusan DKPP sejak ditetapkan dan diucapkan dalam sidang pleno terbuka DKPP. Putusan DKPP bersifat mengikat artinya putusan itu langsung mengikat dan bersifat memaksa sehingga semua lembaga penyelenggara kekuasaan negara dan termasuk badan-badan peradilan terikat dan wajib melaksanakan putusan DKPP itu sebagaimana mestinya. ${ }^{12}$ Pelaksanaan atau eksekusi putusan DKPP itu wajib ditindak-lanjuti oleh KPU, Bawaslu, atau pun oleh pemerintah dan lembaga lain yang terkait.

Sudah cukup banyak penyelenggara Pemilu yang menjadi korban putusan DKPP yang bersifat final dan mengikat. Contoh Putusan DKPP yang memberhentikan penyelenggara Pemilu secara tetap adalah Putusan DKPP No.17/DKPP-PKE-I/2012 $2^{13}$ terhadap seluruh anggota KPU Tulang Bawang karena tidak meloloskan salah satu pasangan bakal calon kepala daerah dalam mengikuti Pemilukada. Putusan DKPP No.70\&71/DKPPPKE-II/2013 ${ }^{14}$ tanggal 2 Agustus 2013 bahkan memberhentikan seluruh anggota KPU dan Panwas Kabupaten Seram Bagian Timur karena terjadinya kecurangan dan pelanggaran kode etik dalam pelaksanaan Pemilukada Provinsi Maluku.

\footnotetext{
12 Jimly Asshiddiqie, op.cit.,

${ }^{13} \mathrm{http}: / / \mathrm{dkpp}$. central.net.id/index.php?mod=maklist\&id=55000000013, diunduh tanggal 2 Februari 2014

${ }^{14}$ http://dkpp.go.id/index.php?mod=pdfview\&page=211, diunduh tanggal 27 Agustus 2015
} 
DKPP sebagai sebuah lembaga atau komisi etik menurut pendapat penulis seharusnya tidak membuat sebuah putusan, melainkan rekomendasi. Putusan DKPP terhadap sebuah pelanggaran kode etik oleh penyelenggara Pemilu tidak dapat bersifat final karena memerlukan persetujuan administrasi lebih lanjut dari KPU dan Bawaslu untuk mengeluarkan Keputusan yang bersifat Final. Dengan prinsip Check and balences antar lembaga negara termasuk penyelenggara Pemilu maka tidak bisa putusan DKPP bersifat final dan mengikat apalagi dalam putusan tersebut memberhentikan penyelenggara Pemilu secara tetap.

KPU dan Bawaslu sebagai lembaga penyelenggara pemilu memiliki kedudukan yang sederajat dengan DKPP, sehingga untuk mengangkat dan juga memberhentikan anggotanya merupakan kewenangan yang mutlak dan mengikat pada lembaga tersebut. KPU dan Bawaslu merupakan lembaga negara permanen yang terstruktur dari pusat hingga kedaerah. Dalam pengangkatan anggotanya melalui suatu mekanisme yang diatur oleh undang-undang dan kemudian ditetapkan dengan suatu Surat Keputusan yang dikeluarkan oleh pejabat setingkat diatasnya. Ketika penyelenggara Pemilu harus diberhentikan juga harus dikeluarkan Surat Keputusan pemberhentiannya yang kewenangan dan ranahnya ada pada yang mengangkatnya dahulu.

Hans Kelsen mengemukakan Teori Stufenbau des Recht ${ }^{15}$, yang menyatakan bahwa "norma-norma hukum itu berjenjang-jenjang dan berlapis-lapis dalam suatu hierarki tata susunan". Pasal 7 ayat (1) UndangUndang Nomor 12 Tahun 2011 tentang Pembentukan Peraturan Perundangundangan menyebutkan jenis dan hierarki peraturan perundang-undangan dari yang tertinggi adalah Undang-Undang Dasar Negara Republik Indonesia Tahun 1945, sampai yang terendah yaitu Peraturan Daerah Kabupaten/Kota.

Putusan DKPP sebagai lembaga penegak kode etik sebenarnya hanya bersifat rekomendasi, sehingga menurut penulis tidak bisa dikategorikan sebagai putusan hukum. Etika merupakan sumber materiil hukum, namun etika tidak dengan lantas menjadi hukum. Ketika suatu etika diformalkan dan ditetapkan oleh pejabat yang berwenang barulah etika tersebut dapat menjadi hukum. Dalam menjatuhkan hukuman, prosedur, dan jenis hukuman pada etika dan hukum diatur dan dilaksanakan secara berbeda.

Putusan yang bersifat final dan mengikat dari sanksi yang dijatuhkan adalah ranah wewenang lembaga pemegang kekuasaan kehakiman. Bahkan dalam lembaga kehakiman pun terdapat mekanisme banding terhadap suatu putusan pengadilan. Menurut penulis norma didalam UU No.15 Tahun 2011 yang menyatakan DKPP menetapkan Putusan merupakan norma yang

${ }^{15}$ Hans Kelsen, General Theory Of Law and State, op.cit., p.. 179 
bertentangan dengan pengaturan tentang Kekuasaan Kehakiman sebagaimana dimaksud dalam Pasal 24 UUD 1945. Sifat Putusan DKPP yang Final dan mengikat tersebut telah menciptakan kondisi tidak adanya mekanisme check and balances antara DKPP dengan KPU dan Bawaslu sebagaimana telah penulis gambarkan dalam pokok bahasan pertama.

\section{c. Pelaksanaan Putusan DKPP}

Salah satu tugas DKPP sebagaimana disebutkan Pasal 111 ayat (3) huruf d Undang-Undang Nomor 15 Tahun 2011 tentang Penyelenggara Pemilu, adalah "menyampaikan putusan kepada pihak-pihak terkait untuk ditindaklanjuti". Dalam penjelasan pasal tersebut yang dimaksud dengan "pihak-pihak terkait" antara lain: pihak yang diadukan, Kepolisian dalam hal pelanggaran pidana, dan Penyelenggara Pemilu. Peraturan DKPP Nomor 2 Tahun 2012 Tentang Pedoman Beracara Kode Etik Penyelenggara Pemilihan Umum, juga menjelaskan dalam Pasal 35 ayat (1) "Putusan DKPP disampaikan kepada Teradu dan/atau Terlapor dan Pengadu dan/atau Pelapor serta pihak-pihak terkait lainnya untuk ditindaklanjuti". Ayat (2) "Dalam hal penelitian atau pemeriksaan yang dilakukan DKPP menemukan dugaan pelanggaran di luar pelanggaran Kode Etik, DKPP menyampaikan rekomendasi kepada lembaga dan/atau instansi terkait untuk ditindaklanjuti”.

Sesuai prosedur tetap yang dimiliki DKPP, sebagai tindak lanjut dari putusan DKPP, bahwa setiap kali sebuah putusan selesai dibacakan dalam suatu sidang DKPP, pihak sekretariat DKPP selalu menindaklanjutinya dengan menyampaikan langsung kepada para pihak, baik Pengadu maupun Teradu. Setiap Putusan DKPP juga disampaikan kepada KPU, KPU Provinsi, dan KPU Kabupaten/Kota dengan maksud agar segera dilaksanakan, sesuai hierarki dalam struktur penyelenggara Pemilu di jajaran KPU. Demikian halnya apabila Teradu adalah jajaran Bawaslu, DKPP menyampaikan kepada Bawaslu untuk dilaksanakan.

Bagi penyelenggara Pemilu di daerah, penyampaian Putusan DKPP disampaikan melalui paket pos kilat tercatat. Di samping itu, agar Putusan DKPP dilaksanakan penyelenggara Pemilu serta diketahui khalayak ramai, sekretariat DKPP selalu memasang iklan layanan masyarakat di media cetak atau media online yang terbit di ibukota dan lokal sesuai daerah di mana teradu atau pihak terkait lain berada. Penyebarluasan putusan tersebut lazimnya disebut "Maklumat Putusan".

Pasal 112 ayat (13) UU No.15 Tahun 2011 menyebutkan "KPU, KPU Provinsi, KPU Kabupaten/Kota, PPK, PPS, PPLN, KPPS, KPPSLN, Bawaslu, Bawaslu Provinsi, Panwaslu Kabupaten/Kota, Panwaslu Kecamatan, PPL dan PPLN wajib melaksanakan putusan DKPP”. Pasal ini merupakan penegaskan dari pasal lainnya yang menyatakan bahwa salah satu tugas KPU dan Jajarannya adalah melaksanakan keputusan DKPP, 
sedangkan Bawaslu memiliki tugas untuk mengawasi pelaksanaan Putusan DKPP. Sebagai konsekuensi dari sifat putusan DKPP yang final dan mengikat, Peraturan DKPP Nomor 2 Tahun 2012 telah mengatur dalam Pasal 34 ayat (2) bahwa "Penyelenggara Pemilu wajib melaksanakan putusan DKPP paling lama 7 (tujuh) hari sejak putusan dibacakan".

Apabila dalam putusan DKPP menyatakan pemberhentian sementara atau tetap kepada penyelenggara Pemilu karena terbukti melanggar kode etik, maka yang bersangkutan akan akan digantikan oleh penyelenggara Pemilu yang lainnya. Dalam hal anggota KPU atau Bawaslu tersebut sedang melaksanakan tugas tahapan Pemilu, maka sementara waktu akan digantikan oleh penyelenggara Pemilu satu tingkat diatasnya.

DKPP merupakan lembaga penegak kode etik yang sejajar dengan penyelenggara Pemilu lainnya. Putusan DKPP sesungguhnya hanya bersifat rekomendasi kepada penyelenggara pemilu, maka menurut penulis tidaklah semua putusan DKPP harus ditindak lanjuti oleh KPU dan Bawaslu, terutama bila putusan tersebut telah melampaui kewenangan DKPP sebagai lembaga penegak kode etik penyelenggara Pemilu. Putusan DKPP dapat ditindak lanjuti hanya sampai sebatas sanksi pemberhentian sementara anggota penyelenggara Pemilu yang melanggar kode etik dari pelaksanaan tugasnya dalam tahapan penyelenggaraan pemilu yang sedang berlangsung. Saksi pemberhentiaan tetap untuk yang bersangkutan selanjutnya merupakan wewenang penyelenggara Pemilu itu sendiri.

Mungkin saja nanti terjadi suatu putusan DKPP dianggap oleh penyelenggara Pemilu melampaui kewenangannya, sehingga KPU dan atau Bawaslu tidak mau melaksanakan putusan DKPP tersebut. Perselisihan hukum yang terjadi antara DKPP dengan KPU dan atau Bawaslu akan menjadi suatu permasalahan hukum baru dalam pelaksanaan Pemilu, yang apabila tidak ada penyelesaianya akan membuat kredibilatas dan kualitas Pemilu diragukan oleh masyarakat. Untuk itu menurut penulis diperlukan terobosan hukum terhadap potensi konflik hukum antar lembaga yang memiliki satu kesatuan fungsi penyelenggara pemilu ini, melalui penyelesaian akhir seluruh sengketa Pemilu di Mahkamah Konstitusi.

\section{Penutup \\ 1. Simpulan}

Pemilihan Gubernur Lampung pada tahun 2014 oleh masyarakat tidak begitu memuaskan atau mengalami krisis, dikarenakan terdapat pelanggaran-pelanggaran pemilu yang ditemukan disana. Setelah munculnya Putusan Dewan Kehormatan Penyelenggara Pemilu No.25/DKPP-PKEIII/2014 menyimpulkan bahwa Bawaslu Provinsi Lampung melakukan 
pelanggaran kode etik dalam melaksanakan Pemilihan Gubernur Lampung Tahun 2014.

Subjek yang dapat diperkarakan selaku pihak teradu/terlapor di DKPP dalam peraturan dibatasi hanya penyelenggara Pemilu tingkat Kabupaten/Kota, Provinsi, dan Pusat. Objek pelanggaran etika yang dapat diperkarakan menyangkut sikap dan perbuatan pribadi penyelenggara Pemilu yang mengandung unsur jahat dan melanggar hukum. Waktu pengajuan perkara suatu pelanggaran kode etik tidak tergantung kapan suatu perbuatan tersebut terjadi, namun dalam suatu penyelenggaraan Pemilu dibatasi pengajuan gugatan pelanggaran kode etik sesuai dengan tahapan pelaksanaan Pemilu. Undang-undang Penyelenggara Pemilu dan Peraturan DKPP menyatakan dengan tegas bahwa Putusan DKPP bersifat final dan mengikat (final and binding) serta penyelenggara Pemilu wajib melaksanakan putusan DKPP.

\section{Saran}

Dengan putusan DKPP yang ke sekian kali nya ini Para penyelenggara Pemilu baik di tingkat provinsi, daerah sampai tingkat desa harus benarbenar netral dan menjalankan tugasnya dengan baik, agar pemimpin yang terpilih yang akan mempimpin di daerah tersebut berlegitimasi dengan baik.

DKPP sebaiknya tidak membuat sebuah Putusan, melainkan sebaiknya Rekomendasi. Putusan DKPP yang bersifat final dan mengikat khusus untuk sanksi pemberhentian tetap, diubah menjadi rekomendasi kepada lembaga penyelenggara pemilu sesuai dengan hirarkinya. Percuma jika penyelenggara Pemilu jika melanggar ketentuan-ketentuan yang berlaku hanya di hukum diberhentikan, jarang dilimpahkan sebagai pelanggaran pidana nya, jika hanya diberhentikan maka tidak membuat para penyelenggara pemilu jera.

\section{Daftar Pustaka}

\section{A. Buku}

Asshiddiqie, Jimly, Perkembangan dan Konsulidasi Lembaga Negara Pasca Reformasi. Sinar Grafika, Jakarta, 2010

Asshidiqie, Jimly Bagir Manan, dkk. Gagasan amandemen UUD 1945 dan Pemilihan Presiden Secara Langsung, cet. Ke-2, Sekertariat Jenderal dan Kepaniteraan Mahkamah Konstitusi RI, Jakarta 2006.

Arifin Firmansyah dkk. Lembaga Negara dan Sengketa Kewenangan antar Lembaga Negara, KHRN bekerjasama dengan MKRI didukung oleh The Asia Foundation dan USAID, Jakarta 2005, hlm. 29 
Derajat kepentingan suatu lembaga berdasarkan undang-undang dasar dalam sistem negara demokrasi konstitusi. Jimly

Hans Kelsen, General Theory of Law and State, Russell \& Russell, New york, 1061, diterjemahkan oleh Raisul Mutaqien, Teori Umum Tentang Hukum dan Negara, Cetakan I, Penenerbit Nusamedia dan Penenrbit Nuansa, Bandung, September 2006

Hamdi, Muchlis "State Auxiliary Bodies di Beberapa Negara”, Disampaikan dalam dialog hukum dan non hukum "Penataan State Auxiliary Bodies dalam Sistem Ketatanegaraan " Departemen Hukum dan HAM RI Badan Pembinaan Hukum Nasional bekerjasama dengan Fakultas Hukum Universitas Airlangga, Surabaya 26-29 Juni 2009

Hendra Nurtjahjo, "Lembaga Independen di Indonesia : Kajian Perspektif Yuridis", Makalah dalam diskusi terbatas tentang Kelembagaan Independen di Indonesia di pusat kajian Hukum administrasi Negara Jakarta, 2006

Hadjar Al Fickar, Pokok-Pokok Pikiran dan Rancangan Undang-Undang Mahkamah Konstitusi, KRHN dan Kemitraan, Jakarta, 2003

Isra, Saldi, Pergeseran Fungsi Legislatif: Menguatnya Model Legislasi Parlementer Dalam Sistem Presidensial Indonesia, Rajawali Pers, Jakarta, 2010.

Mahfud MD, Moh. Politik Hukum di Indonesia, Ed. Revisi, Cet.2. Rajawali Pers, Jakarta, 2009.

Manan, Bagir. Pertumbuhan dan Perkembangan Konstitusi Suatu Negara, Mandar Maju, Bandung, 1995.

Soemantri Sri, "Lembaga Negara dan State Auxiliary Bodies dalam Sistem Ketatanegaraan Menurut UUD 1945", Disampaikan dalam dialog hukum dan non hukum "penataan State Auxiliary Bodies dalam Sistem Ketatanegaraan" Departemen Hukum dan HAM RI, Badan pembinaan Hukum Nasional bekerjasama dengan Fakultas Hukum Universitas Airlangga, Surabaya 26-29 Juni 2009

Soeprapto, Farida Maria Indrati, Ilmu Perundang-undangan, Dasar-Dasar dan pembentukannya, Kanisius, Jakarta, 1998,

Thohari, A.Ahsin, "Kedudukan Komisi-Komisi Negara Dalam Struktur Ketatanegaraan Indonesia”, Jurnal Hukum Jantera, Edisi 12 Tahun III, April 2006,

Yasir, Armen. Hukum Perundang-undangan, Lembaga Penelitian Universitas Lampung, 2008.

\section{B. Internet}

http://www.tokohindonesia.com/biografi/article/286-direktori/2339-terpilihjadi gubernur-lampung unduhan 25-2-2015 
http://www.republika.co.id/berita/breaking-news/nasional/08/09/18/3734-

kpud-lampung-tetap-gelar-rekapitulasi-suara-pilgub unduhan pada 252-2015

Nyoman adi irawan, Mahasiswa Untuk Demokrasi, 2013, http://sidomi.com/280499/hasil-pilgub-lampung-2014-ridho-bakhtiarmenang-versi-quick-count/ unduhan 25-2-2015

http://www.saibumi.com/artikel-2622-hasil-final-rekapitulasi-kpu-ridhoficardo-menangi-pilgub-lampung-dengan-4496-persen.html unduhan 25-2-2015

www.langpung.tribunnews.com/2014/6/09/dkpp-putusan-bawaslu-lampunglanggar-kode-etik unduhan 3-3-2015 